\title{
The mouse Hox-1.3 gene is functionally equivalent to the Drosophila Sex combs reduced gene
}

\author{
Jack Jiagang Zhao, Robert A. Lazzarini, and Leslie Pick \\ Brookdale Center for Molecular Biology, Mount Sinai School of Medicine, New York, New York 10029-6574 USA
}

To test whether the mouse Hox-1.3 gene is a cognate of the Drosophila Sex combs reduced (Scr) gene, we inserted a hsp 70-Hox-1.3 fusion gene into the Drosophila genome. Transgenic flies displayed Scr-like homeotic transformations after ectopic expression of Hox-1.3 induced by heat shock. In larvae, the thoracic segments T2 and T3 are transformed toward T1. In adults, head structures are dramatically disrupted, including transformation of antenna towards leg. Transformations are not the result of ectopic activation of the endogenous Scr gene. Rather, Hox-1.3 appears to directly regulate Scr target genes, as demonstrated by the ectopic activation of fork head by Hox-1.3. The results suggest that mouse Hox-1.3 cannot only substitute functionally for Drosophila Scr in the determination of external structures but also can participate in the regulatory hierarchy of insect organogenesis.

[Key Words: Hox-1.3; Sex combs reduced; fork head; homeotic transformation; evolution]

Received October 16, 1992; revised version accepted January 4, 1993.

The conserved homeo box sequences first found in Drosophila regulatory genes encode a 60-amino-acid residue domain, known as the homeo domain (McGinnis et al. 1984a,b; Scott and Weiner 1984). Substantial genetic evidence demonstrates that mutations in homeo boxcontaining genes can dramatically affect the development of Drosophila. As homeotic mutations have not been found naturally in mice, the mouse homeo boxcontaining (Hox) genes were isolated solely on the basis of homology to Drosophila homeo box sequences. Most Hox genes are tightly linked in four gene clusters (Hox-1, Hox-2, Hox-3, and Hox-4 clusters) on chromosomes 6, 11,15 , and 2 . Based on homeo box sequence similarity, two groups independently observed that the members of the four mouse Hox clusters can be aligned with the Drosophila Antennapedia complex (ANT-C) and Bithorax complex (BX-C) (collectively known as HOM-C) and classified into cognate subfamilies (Duboule and Dolle 1989; Graham et al. 1989; for review, see McGinnis and Krumlauf 1992). Interestingly, the physical order of homeotic genes in Drosophila HOM-C corresponds to the order along the anterior-posterior axis of the segments affected by the genes (for review, see Akam 1987). The correlation between regions of gene expression along the body axis and physical order along the chromosome is also conserved in mouse (Duboule and Dolle 1989; Graham et al. 1989).

In vitro and in vivo studies of Drosophila and mammalian homeo domain proteins indicate that they are transcription factors and that the homeo domain is required for nuclear targeting and sequence-specific DNA- binding activity (Desplan et al. 1985, 1988; Fainsod et al. 1987; Hall and Johnson 1987; Hoey et al. 1988; Müller et al. 1988; Kuziora and McGinnis 1989; Odenwald et al. 1989; Treisman et al. 1989; Kissinger et al. 1990|. These findings, along with the observation that mammalian Hox genes are expressed in a tissue-specific fashion during embryonic development, suggest that Hox genes may play important roles in controlling embryogenesis in vertebrates as do Drosophila homeo box-containing genes. This idea is strongly supported by recent results using homologous recombination to disrupt endogenous Hox genes in mice (Chisaka and Capecchi 1991; Lufkin et al. 1991; Le Mouellic et al. 1992).

The Hox-1.3 gene was identified initially by screening a mouse genomic library with an Antennapedia (Antp) homeo box probe under low stringency (Colberg-Poley et al. 1985). The gene was then characterized by Odenwald et al. (1987) and Fibi et al. (1988). It consists of two exons and one intron. The 270-amino-acid residue Hox-1.3 open reading frame (ORF) is rich in proline, serine, and glycine and is phosphorylated at multiple sites (Odenwald et al. 1989). The homeo domain is located between residues 195 and 254. The protein also contains an octapeptide (MSSYFVNS) and a pentapeptide (IYPWM) that are conserved among many vertebrate and Drosophila homeo box genes (Odenwald et al. 1987). The distribution of Hox-1.3 is progressively restricted during early mouse embryogenesis. In very early embryos, it is expressed in nearly all cells (Tani et al. 1989). In mid-gestation embryos, Hox-1.3 mRNA is expressed at high levels in the mesoderm and neuroectoderm with an anterior 
boundary near the junction of the hindbrain and spinal cord (Dony and Gruss 1987; Fibi et al. 1988). In adults, the mRNA and protein have also been detected in some tissues, including liver, lung, kidney, and central nervous system (Odenwald et al. 1987; Garbern et al. 1989). DNA-binding assays showed that Hox-1.3 high-affinity binding sites contain an ATTA core motif /Odenwald et al. 1989|, which is also the core of Drosophila Antp class high-affinity binding sites (for review, see Scott et al. 1989|. Nevertheless, the biological function of Hox-1.3 is unknown.

If homeo box-containing genes play a basic role in embryonic development that is conserved throughout the animal kingdom, they would be under selective pressure to maintain certain functional specificities during evolution. One way to test this notion is to assay the ability of a given homeo box-containing gene from one organism to functionally substitute for a putative cognate gene in another organism. Two previous studies have shown that the mouse Hox-2.2 and human Hox-4.2 genes can carry out some of the functions of their Drosophila cognates when introduced into flies (Malicki et al. 1990; McGinnis et al. 1990).

We have chosen to use the mouse Hox-1.3/Drosophila Sex combs reduced (Scr) putative cognate pair as a model to examine the functional conservation of $H o x$ genes at both morphological and regulatory levels. We have inserted the mouse Hox-1.3 ORF into the Drosophila genome under the control of a Drosophila heat shock promoter $(h s p 70)$ that gives rise to ubiquitous expression after heat treatment. Abnormalities induced by the ectopic expression of Hox-1.3 protein during both embryonic and larval phases of development were Scr-like. These results strongly suggest that mouse Hox-1.3 is the bona fide cognate of $S c r$ but not the closely related and neighboring Antp gene. We show further that the mouse Hox-1.3 gene can participate in Drosophila regulatory networks by activating the fork head (fkh) gene, a downstream target of Scr. Thus, the functional properties of this cognate pair appear to have been conserved $>600$ million years since the divergence of vertebrates and arthropods.

\section{Results}

Expression of the mouse Hox-1.3 gene in transgenic flies

The mouse Hox-1.3 and three Drosophila homeo domain proteins (Scr, Antp, and Dfd) are highly homologous in the homeo domain (Fig. 1A). In addition, two other short regions (Odenwald et al. 1987), one at the amino terminus of the proteins (the octapeptide) and the other just adjacent to the homeo domain (the pentapeptide), are also highly conserved among these proteins. However, the overall similarity of the 270 -amino-acid Hox- 1.3 protein to the three is low: $28 \%(75$ amino acids) to $S c r$; $26 \%$ (70 amino acids) to Antp; and 24\% (66 amino acids) to Deformed $(D f d)$. Because of the slightly higher degree of sequence similarity and the position of Hox-1.3 in the
A

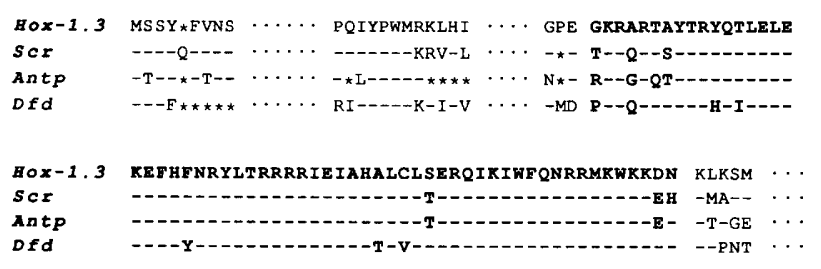

B

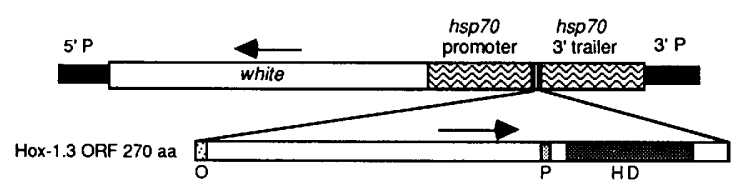

Figure 1. Hsp70-Hox-1.3 transgene constructs and amino acid sequences comparison. (A) Alignment of mouse Hox-1.3 amino acid sequences with three Drosophila homeotic gene products Scr, Antp, and Dfd [Scr (LeMotte et al. 1989), Antp (Schneuwly et al. 1986), Dfd (Regulski et al. 1987)]. Within the conserved domains, identical residues are marked with a broken line. Homeo domain residues are in boldface type. The asterisks $(*)$ indicate missing positions in terms of alignment. The dots represent large nonconserved regions (not to scale). $(B)$ Schematic representation of pCaSpeR-hs-Hox-1.3 transgenic plasmids. The vector contains the mini white $\left(w^{+}\right)$gene flanked by the ends of the P transposon (Pirotta 1988). The multiple cloning site separates the $h s p 70$ promoter $(-245$ to +207$)$ from the $h s p 70$ trailer sequences (a 525-bp fragment-containing polyadenylation site). The full-length Hox-1.3 cDNA was inserted into the polylinker sites (see Materials and methods). The orientations of Hox-1.3 and white ORFs are indicated by arrows. Besides the homeo domain (HD), two other short conserved regions are indicated by $\mathrm{O}$ (the octapeptide) and $\mathrm{P}$ (the pentapeptide).

Hox-1 cluster, the mouse Hox-1.3 gene was proposed to be a cognate of the Scr gene (Duboule and Dolle 1989; Graham et al. 1989).

We examined the potential Scr-like function of Hox1.3 protein in transgenic flies by placing the Hox-1.3 gene under the control of a heat-inducible-promoterhsp70 (Fig. 1B). The full-length Hox-1.3 ORF (Odenwald et al. 1987) was inserted between the Drosophila hsp70 promoter and trailer sequences in the P-element vector CaSpeR-hs (Pirotta 1988) to create the fusion gene hsHox-1.3. The construct was inserted into the Drosophila genome by P-element-mediated transformation (Rubin and Spradling 1982; Spradling and Rubin 1982). Ten hsHox-1.3 independent transformant lines were generated, and all described phenotypes were observed in at least three independent lines.

Under normal growth conditions $\left(25^{\circ} \mathrm{C}\right)$, transformant embryos carrying $h s-H o x-1.3$ do not express detectable levels of Hox-1.3 proteins (Fig. 2A). However, after a 1-hr heat shock, Hox-1.3 protein products are distributed in most nuclei of the embryo (Fig. 2B). The expressed Hox1.3 protein products persist in the embryo and are still abundant even after $3 \mathrm{hr}$ of recovery at $25^{\circ} \mathrm{C}$ (Fig. 2C). To 


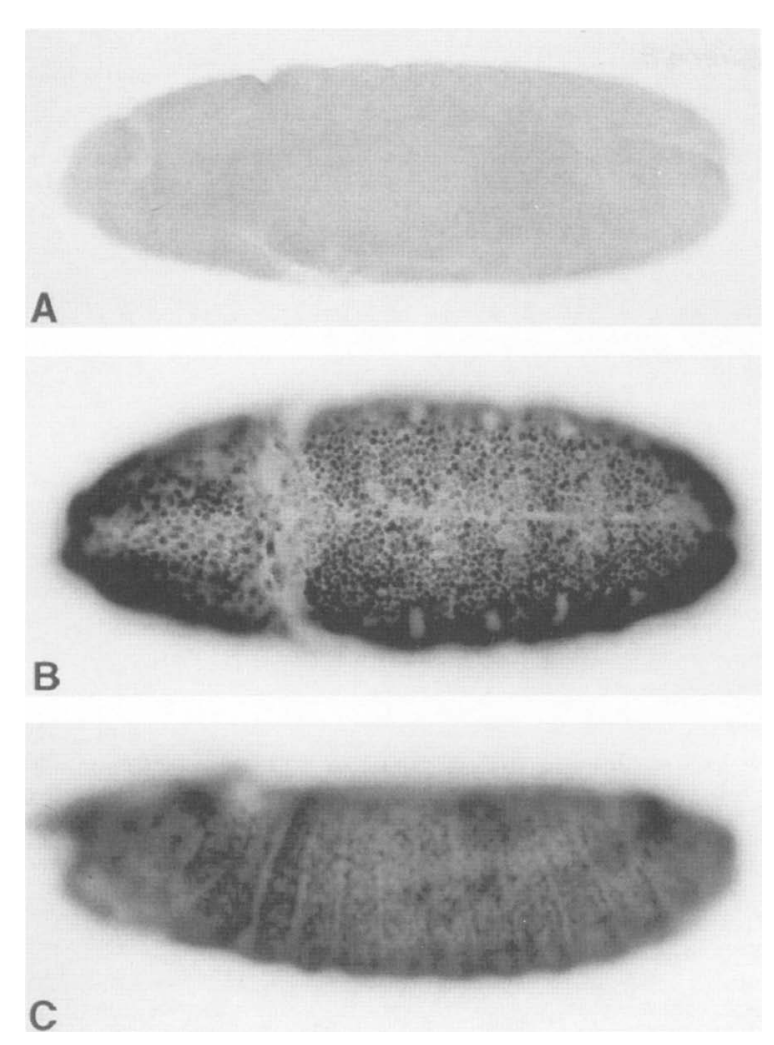

Figure 2. Induction of mouse Hox-1.3 protein in transgenic embryos. (A) No Hox-1.3 protein is detected in the non-heatshocked transgenic embryos at the germ-band extension stage. (B) Heat-induced expression of Hox-1.3 in hs-Hox-1.3-bearing embryos. Hox-1.3 protein was detected by immunostaining with anti-Hox-1.3 antibodies after $1-\mathrm{hr}$ recovery at $25^{\circ} \mathrm{C}$ following a $1-\mathrm{hr}$ heat shock at $6 \mathrm{hr}+30 \mathrm{~min}$ AEL. (Note that the signal is located in the nuclei of all embryonic cells.) $(C)$ Embryos were heat treated as in $B$, but immunostaining was carried out after $3 \mathrm{hr}$ of recovery at $25^{\circ} \mathrm{C}$.

rule out general effects of heat shock and protein ectopic expression, we also inserted a Hox-1.3 gene fragment lacking the coding sequence for the homeo domain and part of the carboxyl terminus into the Drosophila genome. The protein products of the truncated form are detected in the cytoplasm of the cell (data not shown).

\section{Homeotic transformations induced by ectopic expression of Drosophila Scr}

To compare the morphological consequences induced by ectopic expression of the mouse Hox-1.3 and Drosophila Scr genes in transgenic flies, we have re-examined the defects produced in $h s-S c r$ flies. Here, we expand the description of the induced phenotypes.

Larval transformations were induced optimally by a 1-hr heat shock $\left(37^{\circ} \mathrm{C}\right)$ of hs-Scr-bearing embryos at 6 $\mathrm{hr}+30 \mathrm{~min}$ after egg laying (AEL). The cuticular phenotypes were essentially the same as reported previously (Gibson et al. 1990). Briefly, $>80 \%$ of heat-shocked hsScr cuticles display thoracic transformation, although to varying degrees. Compared with a wild-type larva (Fig. $3 \mathrm{~A}$ ), the transformation is marked by the unique $\mathrm{T} 1$ ventral beards appearing ectopically in the T2 and T3 segments (Fig. 3B). After a 1-hr heat shock, most resulting hs-Scr larvae have the $\mathrm{T} 2$ toward $\mathrm{T} 1$ transformation, and $70 \%$ of them had $\mathrm{T} 1$ epidermal identity in both $\mathrm{T} 2$ and T3. Shorter heat shocks (e.g., $20 \mathrm{~min}$ ) stimulate ectopic beards only in T2 (data not shown). Additional effects induced by ectopic expression of $S c r$ are found in the head segments of resulting larvae. Head involution is disrupted, and the cephalopharyngeal skeleton is dramatically reduced. The extent of malformation in various head structures is variable and depends on the time and length of heat shock. Even though there is a strong transformation of $\mathrm{T} 3$, no transformation of abdominal segments was observed in these $h s-S c r$ cuticles.

In the adult, morphological changes were induced by treating $h s-S c r$-bearing larvae with multiple heat shocks starting at late second-instar or early third-instar larval stage, as described in Materials and methods. The result is largely consistent with a previous report (Gibson et al. 1990). Compared with a normal head (Fig. 3C), the aberrant expression of $S c r$ leads to a dramatic reduction of the compound eyes (observed in 42 of 45 flies), induces aristae to tarsal transformation (or thickened aristae, observed in 40 of 45 flies; Fig. 3D), and causes disfigured maxillary palps, labial palps (observed in 24 of 45 flies; Fig. 3E), and swollen occiputs with many thickened bristles in the hindhead (observed in 30 of 45 flies; Fig. 3F). The occiput transformation is similar to a phenotype induced by ectopic expression of Antp (Schneuwly et al. 1987; Gibson and Gehring 1988) and a natural dominant mutation Cephalothorax $(C t x)$ in the Antp complex (Duncan and Lewis 1982). The hindhead seems to be a sensitive and plastic region that can be modified to thoracic identity by both $A n t p$ and $S c r$ genes.

\section{Homeotic transformations induced by the ectopic expression of mouse Hox-1.3}

To compare the phenotypic consequences of ectopically expressed mouse Hox-1.3 to those of Scr, $\sim 5.5$ to $6.5-\mathrm{hr}-$ old $h s-H o x-1.3-b e a r i n g$ embryos were subjected to heat treatment at $37^{\circ} \mathrm{C}$ for $1 \mathrm{hr}$, as was done for hs-Scr-bearing embryos. As shown in Figure 4B, the larvae display Scr-like transformations (cf. Fig. 3B). Characteristically, mouse Hox-1.3 induces the transformation of thoracic segments $\mathrm{T} 2$ and $\mathrm{T} 3$ toward $\mathrm{T} 1$. The ventral beard, a unique feature of $\mathrm{T} 1$, clearly appears in the $\mathrm{T} 2$ and $\mathrm{T} 3$ thoracic segments. The thoracic segment transformation induced in hs-Hox-1.3 animals is Scr-like but it is not Antp-like, because the ectopic expression of Antp causes the loss of the Tl ventral beard, an antagonistic transformation to that induced by Scr (Gibson and Gehring 1988; Gibson et al. 1990). Other obvious abnormalities caused by misexpression of Hox-1.3 are the failure of head involution and the absence or misplacement of many cuticular head structures (e.g., epistomal sclerite, ectostomal and hypostomal sclerites, the pigmented H-piece, the mouth hooks, and sensory organs). Trans- 

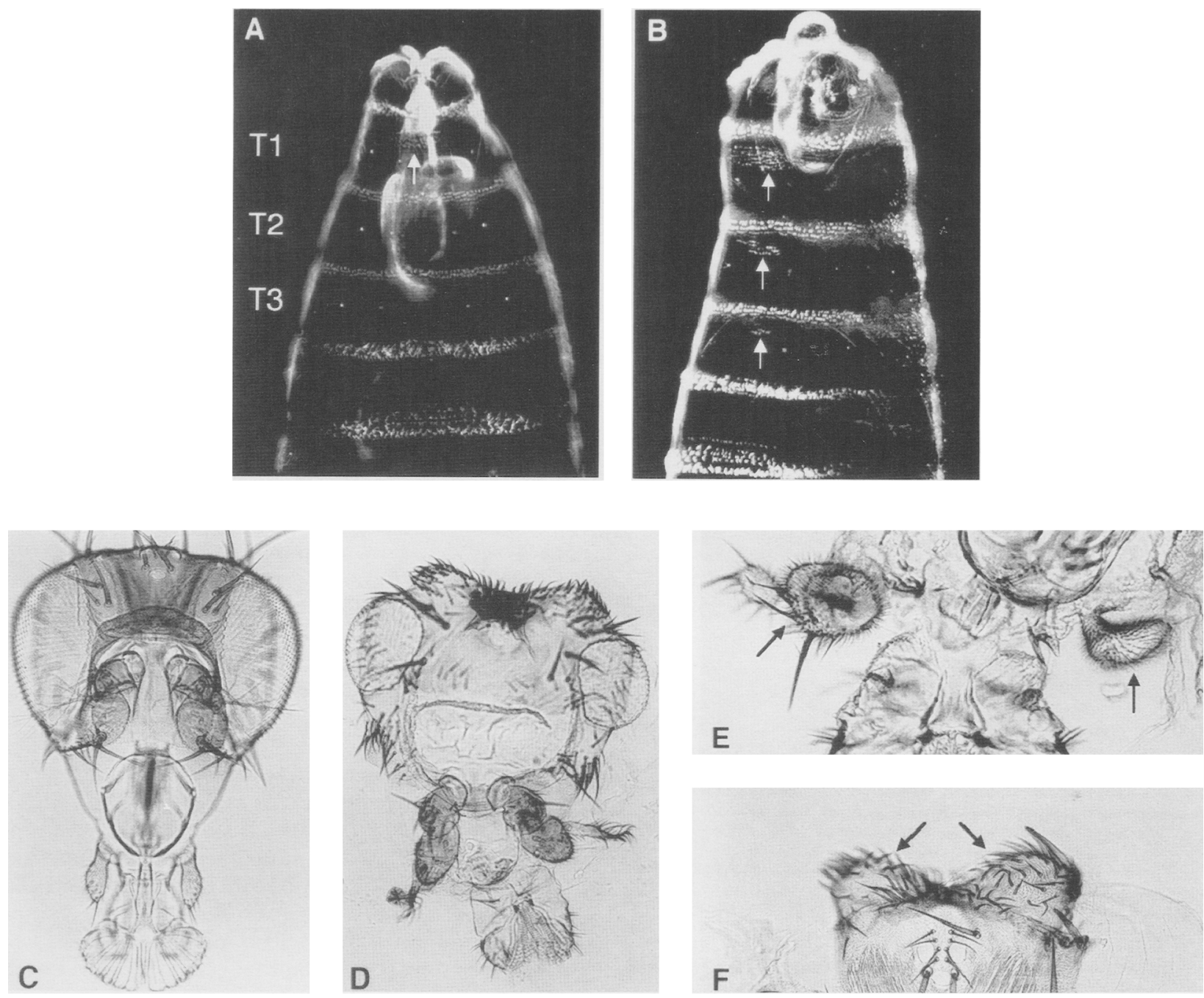

Figure 3. Transformations resulting from ectopic expression of Drosophila Scr. $(A)$ Wild-type first-instar larva cuticular structures. The arrow indicates the ventral beard that marks the first thoracic segment (T1). $(B)$ Morphological consequences induced by ectopic expression of $S c r$ in $h s-S c r$-bearing embryos. Embryos were subjected to a 1-hr heat shock at $6 \mathrm{hr}+30$ min AEL and allowed to develop to larvae. Authentic and ectopic T1 beards of a first-instar larva are indicated by the arrows. $(C)$ Wild-type adult head. $(D)$ An example of phenotypes induced in the adult head by misexpression of $S c r$ during larval development (see text for details). (E) The malformed mouth parts of a heat-shocked $h s-S c r$-bearing animal. Note that the maxillary palps are severely disfigured (arrows). (F) The dorsal head of a heat-shocked $h s-S c r$-bearing animal. The arrows indicate the Ctx-like transformation.

formation of cuticular pattern is not detectable in abdominal segments. Embryos carrying the Hox-1.3 fragment lacking homeo domain-coding sequence are still able to hatch after heat shock, and the larval cuticles are indistinguishable from that of wild-type larvae (data not shown), as are those of non-heat-shocked hs-Hox-1.3bearing embryos (Fig. 4A).

To test whether the ectopic expression of Hox-1.3 could induce $S c r$-like homeotic transformations in adult animals, $h s-H o x-1.3$ - bearing larvae were subjected to one or more heat treatments at varying stages of development. Ectopic expression of Hox-1.3 reproduced all Scr-like transformations in the external head structures of transgenic flies (Fig. 5A, cf. Fig. 3D). Although some flies eclosed after heat treatment, many of the phenotypes were observed in animals that were dissected from pupal cases. The abnormalities include reduced and irregular compound eyes (observed in 157 of 203 flies), malformation of mouth parts (observed in 91 of 203 flies), and thickening of the arista (observed in 102 of 203 flies). We have often observed a Ctx-like transformation in the hindhead (155 of 203 flies). Intriguingly, the antenna is transformed toward a relatively well-formed leg (observed in 42 of 203 flies; Fig. 5B). For hs-Hox-1.3 animals, this antenna toward leg transformation could be induced by even a single 1 -hr heat shock between 63 and $93 \mathrm{hr}$ AEL (observed in 10 of 65 flies). Occasionally, structures strongly resembling sex comb teeth were seen 


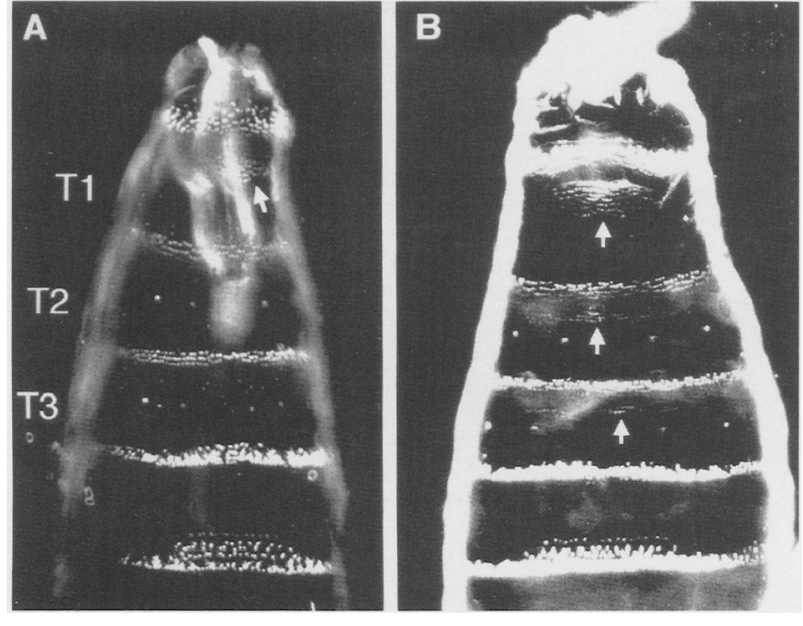

Figure 4. Ectopic expression of mouse Hox-1.3 induces segmental transformations in Drosophila larva. $(A)$ Cuticular pattern of a non-heat-shocked $h s-H o x-1.3$ bearing first-instar larva. There is no transformation detected (cf. the wild-type larva in Fig. 3A). The Tl beard is indicated by an arrow. (B) Embryos carrying the $h s-H o x-1.3$ fusion gene were subjected to a $1-\mathrm{hr}$ heat shock at $6 \mathrm{hr}+30 \mathrm{~min}$ AEL and $37^{\circ} \mathrm{C}$ and allowed to develop to larvae. A typical first-instar larva is shown. Authentic and ectopic T1 beards are indicated by arrows.

on the well-transformed antennal legs (Fig. 5C), suggesting that the ectopic legs have T1 leg identity. In contrast, ectopic expression of Antp (hs-Antp) induces transformation of antenna toward T2 leg, as indicated by the presence of an apical bristle on the ectopic leg (Schneuwly et al. 1987; Gibson and Gehring 1988). We have never observed an apical bristle on the $h s-H o x-1.3-i n-$ duced ectopic legs. In some hs-Hox-1.3 adult heads, the maxillary palps were severely affected and split into two segments (Fig. 5D). This morphological consequence is similar to the transformation described previously for $h s-D f d$ and hs-Hox4.2 transgenic flies (McGinnis et al. 1990). As for the embryonic phenotype, no transformation was observed in embryos carrying the Hox-1.3 fragment lacking the homeo domain (data not shown). Thus, these transformations are not the result of nonspecific effects of heat shock. In addition, the homeo domain is required for all transformations observed.

\section{Hox-1.3 action is not mediated by Drosophila homeotic genes}

Because Hox-1.3 can cause Scr-like homeotic transformations of posterior thoracic segments toward $\mathrm{T} 1 \mathrm{in} \mathrm{em}$ bryos and $S c r$ - and $D f d$-like defects in the adult head, we investigated whether the induced defects might result from activation of the endogenous $S c r$ and/or $D f d$ genes. For these purposes, we compared the localizations of Scr and Dfd proteins in treated hs-Hox-1.3 embryos with wild-type embryos by immunostaining. In wild-type embryos, Scr protein is present in the anterior compartment of $\mathrm{Tl}$, in the labial segment, and in a small group of cells in the posterior region of the maxillary segment at the germ-band-extension stage (Riley et al. 1987; LeMotte et al. 1989). Dfd protein is localized to the maxillary and mandibular segments (Jack et al. 1988).

In heat-shocked hs-Hox-1.3-bearing embryos, $\mathrm{Scr}$ and $D f d$ expression appears normal. No expansion of expression of $S c r$ or $D f d$ in either posterior or anterior direction has been observed (Fig. 6A, B), although there are abundant Hox-1.3 protein products in the whole embryo (see
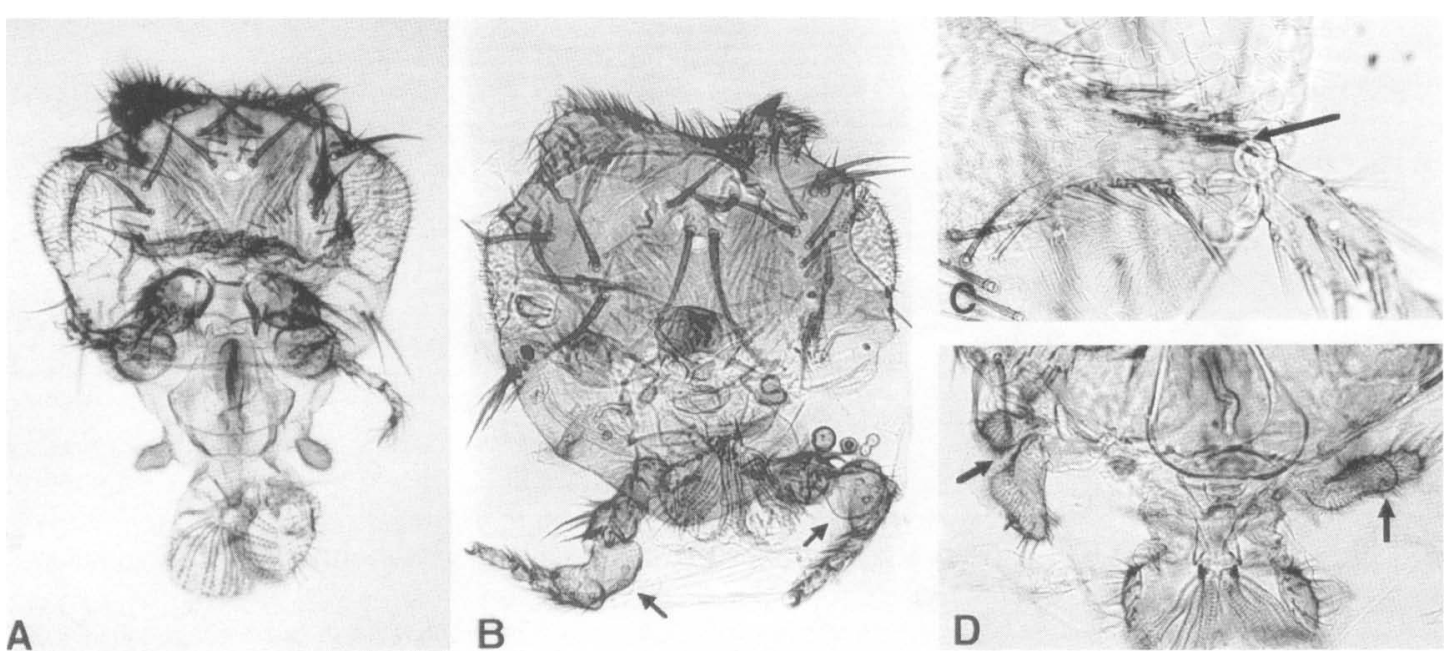

Figure 5. Adult phenotypes induced by ectopic expression of mouse Hox-1.3. $(A)$ Adult head phenotypes induced by misexpression of hs-Hox-1.3. Larva carrying the hs-Hox-1.3 fusion gene were subjected to multiple heat shocks (see Materials and methods). Typical transformations shown include the thickening of the arista, small compound eyes, irregular shape of maxillary palps, and Ctx-like transformation on the dorsal head. $(B)$ One example of transformation of antenna toward leg in a hs $-H o x-1.3 \mathrm{fly}$. Arrows indicate the ectopic legs. $(C)$ High-power magnification showing a sex comb tooth (arrow) on an ectopic leg. $(D)$ Malformations of mouth parts induced by improper expression of Hox-1.3. [Note the maxillary palps are split into two segments (arrows)]. 


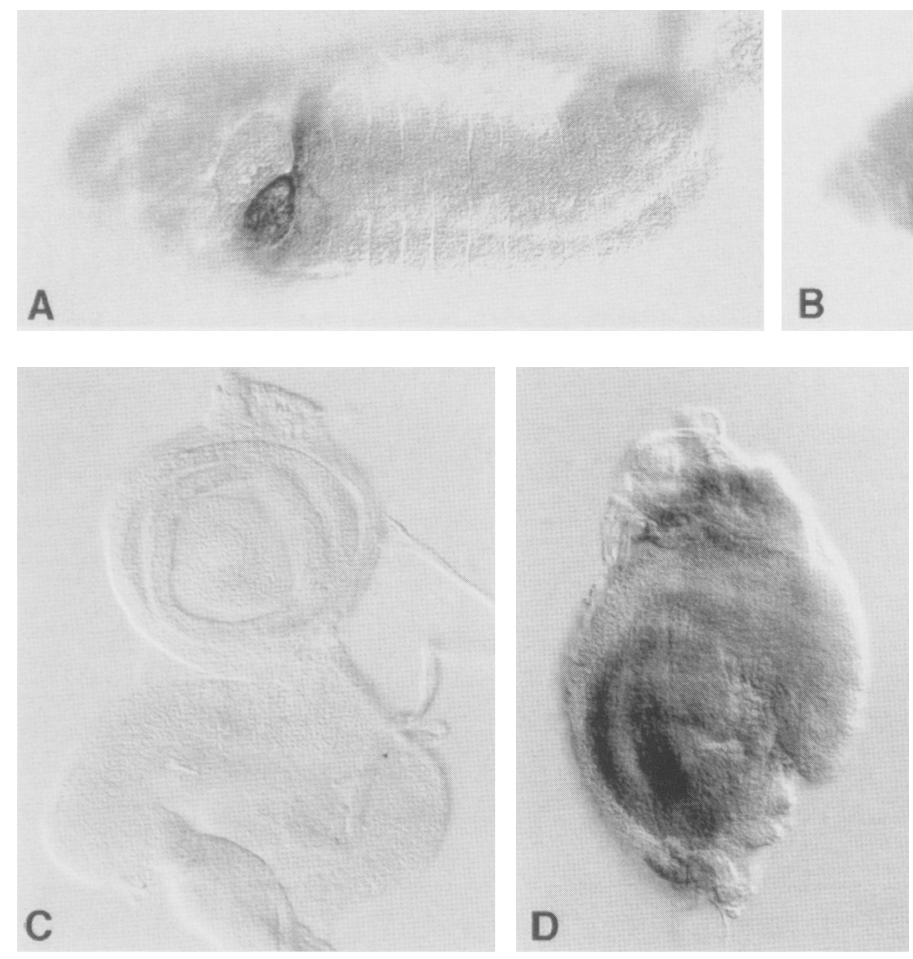

Figure 6. The expression patterns of Drosophila $\mathrm{Scr}$ and $D f d$ are not affected by Hox-1.3. Embryos carrying the hsHox-1.3 fusion gene were subjected to a $1-\mathrm{hr}$ heat shock at $6 \mathrm{hr}+30 \mathrm{~min} \mathrm{AEL}$ and $37^{\circ} \mathrm{C}$ and allowed to recover at $25^{\circ} \mathrm{C}$ for $3 \mathrm{hr}$ (for Scr immunostaining) and $2 \mathrm{hr}$ (for Dfd immunostaining). Expression patterns of Scr $(A)$ and Dfd $(B)$ proteins were detected by immunostaining. No difference from wild-type patterns was detected. For $C$ and $D$, larvae were subjected to two $1-\mathrm{hr}$ heat shocks at the thirdinstar larval stage (see Materials and methods). No ectopic expression of Scr was detected in the eye-antennal imaginal disc $(C)$, whereas expression in $\mathrm{T} 1$ leg discs was normal $(D)$. Thus, ectopic expression of Hox-1.3 did not induce the endogenous Scr gene.

Fig. 2C). We conclude that the endogenous $S c r$ and $D f d$ genes are not activated by Hox-1.3 in heat-treated embryos. Furthermore, Antp gene expression was normal in heat-shocked hs-Hox-1.3-bearing embryos /data not shown). Similar experiments were carried out to test the role of endogenous $S c r$ in inducing the observed adult phenotypes. Larvae were subjected to two heat shocks, as described previously. Although strong transformations were observed in adults in these experiments, no ectopic expression of $S c r$ was observed in eye-antennal discs (Fig. 6C). In addition, we have observed Hox-1.3induced embryonic transformations in $S c r$ mutant animals (data not shown). These results are consistent with the lack of genetic evidence that the endogenous $S c r$ gene is autoregulated and strongly suggest that Hox-1.3 is acting directly to regulate the downstream targets of $S \mathrm{cr}$.

\section{Hox-1.3 activates $\mathrm{fkh}$, a target gene of Scr}

Drosophila $S c r$ is expressed in the primordia of the salivary gland and is required for its development (Panzer et al. 1992). One of the $S c r$ target genes involved in this process is $f k h$, a transcription factor participating in the development of the salivary gland and gut (Weigel et al. 1990). In Scr null mutant embryos, no $f k h$ expression and no salivary placode are detected, whereas misexpression of $S c r$ induces ectopic salivary placodes in the procephalon, in parasegments 1 and 3, and in A8 (Panzer et al. 1992). A $f k h-l a c Z$ fusion gene containing a $f k h$ salivary gland-specific enhancer element directs $l a c Z$ expression specifically in salivary placodes of early embryos (strain P[ry ${ }^{+}$, HNK01]; Panzer et al. 1992; Fig. 7A). This fusion gene responds to $S c r$ overexpression as does the endogenous $f k h$ gene (see Fig. 7B; Panzer et al. 1992). To test the ability of mouse Hox-1.3 to participate in the salivary gland regulatory pathway of Drosophila, we crossed the hs-Hox-1.3 strain with $\mathrm{P}\left[\mathrm{ry}^{+}\right.$, HNK01]. After a 30-min heat shock of 1- to 4-hr-old hybrid embryos and recovery at $25^{\circ} \mathrm{C}$ for $6 \mathrm{hr}$, ectopic expression of the $f k h-l a c Z$ fusion gene is observed. $\beta$-Galactosidase is detected ectopically in the procephalon and in small patches in ventrolateral parts of almost all other parasegments (Fig. 7C). This expression pattern is very similar to that induced by ectopic Scr expression (cf. Fig. 7B). Thus, the mouse Hox1.3 gene mimics the effects of $S c r$ in regulating the expression of the $f k h$ gene.

\section{Discussion}

The ectopic expression of mouse Hox-1.3 mimics Scr homeotic transformations

In this paper we show that the mouse Hox-1.3 can induce specific homeotic transformations when ubiquitously expressed in Drosophila. These transformations are similar to those morphological consequences induced by ectopic Scr gene expression.

After a 60-min heat shock to germ-band-extended embryos, first-instar larvae bearing either $h s-S c r$ or $h s-H o x$ 1.3 display a prominent abnormality in the thoracic region. The two posterior segments (T2 and $\mathrm{T} 3$ ) gain $\mathrm{T} 1$ epidermal identity evidenced by the presence of ectopic ventral beards. This transformation must result from the presence of Scr/Hox-1.3 proteins in the whole thoracic 


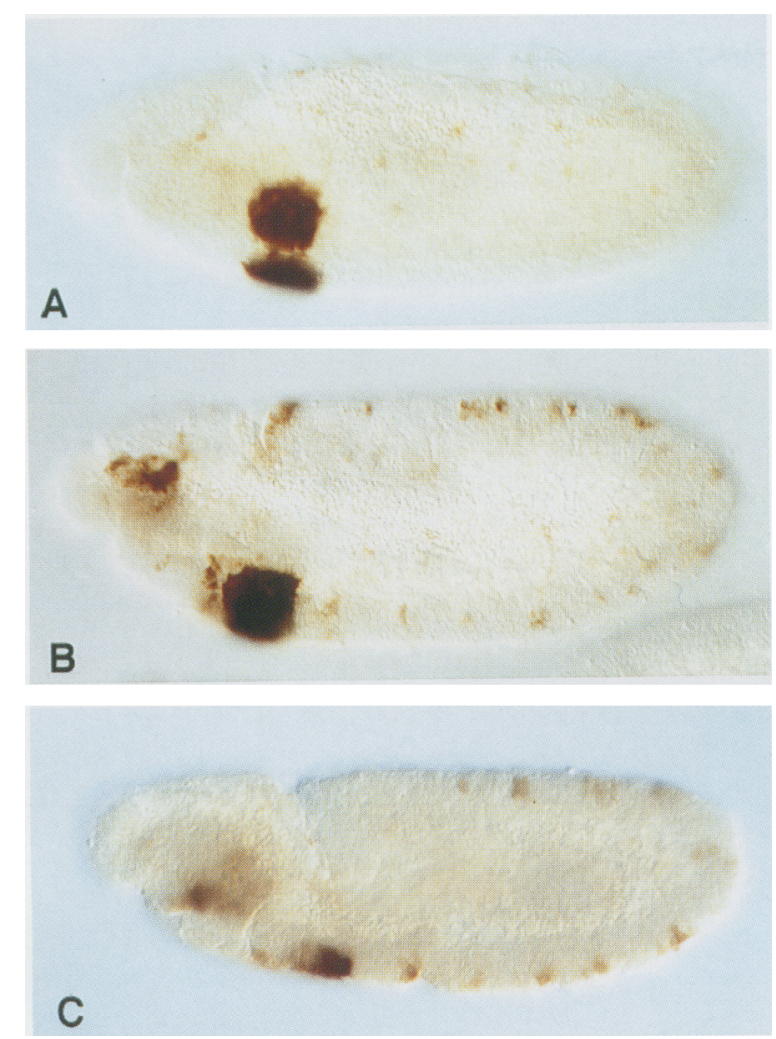

Figure 7. Ectopic expression of a $f k h-l a c Z$ fusion gene induced by misexpression of mouse Hox 1.3. (A) The expression of the $f k h-l a c Z$ fusion gene in HNK0l transformant embryos was detected with anti- $\beta$-galactosidase antibodies. (Note the prominent band of expression in the salivary gland primordia.) $(B, C)$ Hybrid embryos carrying either hs-Scr and fkh-lacZ (B) or hsHox-1.3 and $f k h-l a c Z(C)$ were subjected to a 30-min heat shock at $1-4 \mathrm{hr}$ AEL and $37^{\circ} \mathrm{C}$ and allowed to develop at $25^{\circ} \mathrm{C}$ for another $6 \mathrm{hr}$. $f \mathrm{kh}-1 \mathrm{acZ}$ expression is detected in patches that extend to the posterior segments of the embryo in each case. Embryos at the germ-band extension stage are shown (lateral view).

region, which reprograms the fate of ventral beard precursor cells and, possibly, additional thoracic precursors by overriding the effects of Antp and Ubx activities in this region. These results suggest that there must be strict selective pressure to maintain the $S c r$ expression pattern within sharp boundaries. Other morphological abnormalities are displayed mainly in head segments, including the failure of head involution and the absence or misplacement of head structures. However, these alterations may not reflect the functional specificity of $\mathrm{Scr}$ and Hox-1.3, as ectopic expressions of other Drosophila homeotic selector genes and a mouse cognate of Antp (Hox-2.2) also generated similar abnormalities (Gibson and Gehring 1988; Kuziora and McGinnis 1988; Malicki et al. 1990; Mann and Hogness 1990).

More dramatic homeotic transformations are generated in adult animals after heat treatment of the larvae, the most striking being a transformation of antenna toward leg. These legs appear to correspond to T1 legs be- cause sex comb teeth were displayed in a few hs-Hox-1.3 male pupae. This result strongly indicates that the transformation is Scr-specific because one of the functions of Scr is to produce sex combs on Tl legs of male flies (Pattatucci et al. 1991). The transformation of antenna toward leg by Hox-1.3 is stronger than that induced by $\mathrm{Scr}$ and is detected with a higher frequency (observed in 42 of 203 flies examined). This rather surprising observation may be explained by the increased viability of hs-Hox-1.3 flies as compared with $h s-S c r$ flies after heat shock. Under equivalent conditions, we found that more $h s-H o x-1.3$ flies develop to adult than do $h s-S c r$ flies. This most likely results from the mouse Hox-1.3 having lost functions present in the Drosophila Scr that prevent development during larval and pupal stages. Thus, the potential for stronger transformation of antenna toward leg is uncovered in animals that can develop to adult.

In addition to antennal transformations, both Scr and Hox-1.3 induce a Ctx-like transformation in adult flies (swollen occiputs with many dark ectopic bristles in the dorsal aspect of hindhead; Duncan and Lewis 1982; Schneuwly et al. 1987; Gibson and Gehring 1988). At present, we are unable to determine the segmental identity of this transformation and, thus, cannot distinguish between Antp- and Scr-induced effects on these structures. Unlike dominant $S c r$ mutant males that have ectopic sex comb teeth on both T2 and T3 legs (Pattatucci et al. 1991), hs-Scr and hs-Hox-1.3 adult animals do not exhibit a posterior leg toward foreleg transformation. Perhaps the timing or persistence of heat-induced expression differs from that of the Scr protein produced in dominant gain-of-function mutants. It is possible that in these mutants, a rearranged cis-acting regulatory element leads to ectopic expression of Scr exclusively in the primordial cells of the $\mathrm{T} 2$ and $\mathrm{T} 3 \mathrm{leg}$ imaginal discs that have the potential to generate sex combs. In this case, adults with ectopic T2 and T3 sex combs might not be observed because animals subjected to heat treatment sufficient to induce high levels of $S c r$ expression in these specific cells die as a result of poisoning effects of Scr in other parts of the larva.

\section{The anterorized transformation in heat-shocked larvae containing $\mathrm{Scr} / \mathrm{Hox}-1.3$}

As shown in Figure 3, the misexpression of $S c r$ causes transformation of $\mathrm{T} 2$ and $\mathrm{T} 3$ toward $\mathrm{T} 1$. The anterorization is probably the result of the ectopic presence of Scr protein products in $\mathrm{T} 2$ and $\mathrm{T} 3$, because it is similar to the phenotype of Antp recessive mutants where Scr proteins can be found in T2 and T3 (Riley et al. 1987). This observation is consistent with the model that posteriorly acting homeotic genes normally down-regulate anteriorly acting genes in the thoracic region. For instance, Antp can repress Scr (Riley et al. 1987) and Ultrabithorax (Ubx) can repress Antp (Hafen et al. 1984; Harding et al. 1985). Thus, the improper expression of $S c r$ can override Antp and $U b x$ in two other thoracic segments (T2 and $\mathrm{T} 3$ ) and cause them to gain the epidermal identity of a T1 segment that is normally determined by Scr. Ec- 
topic expression of Antp leads to a transformation of T1 to T2 identity (Gibson and Gehring 1988). T3 is not transformed, presumably because its identity normally is determined by both Antp and $U b x$. A transient excess of Antp protein cannot override $U b x$ activity and alter the developmental program of T3. Ectopic expression of $U b x$, which normally determines T3 /together with Antp) and Al (alone) segment identities, causes a transformation of all thoracic segments toward Al (GonzálezReyes and Morata 1990; Mann and Hogness 1990).

Why does the anteriorized transformation not occur in all abdominal segments of embryos in which anteriorly acting genes are ectopically expressed? One explanation is that $\mathrm{BX}-\mathrm{C}$ gene products present in abdominal segments are functionally dominant to ANT-C gene products such that ectopic expression of ANT-C genes cannot override their effects in abdominal segments even when expressed at high levels, a phenomenon termed phenotypic suppression/González-Reyes and Morata 1990; González-Reyes et al. 1990; Mann and Hogness 1990). Thus far, almost all reported homeotic transformations induced by misexpression of HOM-C genes fit within this model. Nevertheless, our results and a previous paper (Panzer et al. 1992) demonstrate that this model may not be suitable for explaining other sorts of transformations. $f k h$, a downstream gene of $S c r$, can be activated ectopically in the ventrolateral epithelial cells of most posterior segments by overexpression of either Scr or Hox-1.3 (see Fig. 7). Apparently, the functional dominance of BX-C genes is not applicable to this subset of cells in posterior segments. Consistent with this idea, ectopic expression of ANT-C genes also altered the developmental program of the peripheral nervous system in the abdominal segments (Heuer and Kaufman 1992). Thus, when markers for individual cell identity are utilized, transformation can be observed at a cellular level along the entire anterior-posterior body axis. These transformations may not be manifested at the level of morphological change in cuticular pattern, because of the large number of cells and/or sets of genes in each individual cell that must be simultaneously reprogrammed to produce such a dramatic phenotypic change as segmental transformation.

\section{A primordial gene for Hox-1.3 and Scr}

Several investigators proposed that a common ancestor for vertebrates and arthropods contained five homeotic genes in a primordial cluster (Duboule and Dolle 1989; Graham et al. 1989; McGinnis and Krumlauf 1992). These genes were arrayed in an order corresponding to $l a b, p b, D f d$, one of $S c r / A n t p$, and $A b d-B$ of the HOM-C of Drosophila. Akam et al. (1988) suggested that $S c r$, $U b x$, and $A b d-A$ emerged after the divergence of vertebrates and arthropods by duplication of a single Antplike primordial gene. As shown in Figure 1A, Hox-1.3 shares 55 of 61 amino acids within the homeo domain of both Antp and Scr, leaving the assignment of primordial gene identity ambiguous. Our observations demonstrate that despite this sequence similarity, Hox-1.3 is func- tionally equivalent to $S c r$ and not to Antp. In addition, Hox-1.3 shares more homology to Scr than to Antp because of the conserved octapeptide and pentapeptide regions (see Fig. 1A). This homology suggests that Hox-1.3 and $S c r$ arose from a single primordial gene, although we cannot rule out convergent evolution of Scr and Hox-1.3.

The results presented here reflect the strongest conservation of functional specificity among the three cognate pairs of Hox genes that have been examined. In the $D f d / H o x-4.2$ case, the resulting transformation is probably the consequence of activation of endogenous $D f d$ by ectopic expression of a human cognate Hox-4.2 (McGinnis et al. 1990). In embryos carrying the mouse Hox-2.2 transgene, an Antp-like transformation was not dependent on the activation of the endogenous Antp gene (Malicki et al. 1990). However, there is a difference between the cuticular phenotypes induced by Antp and Hox-2.2. Hox-2.2 has little effect on the morphology of $\mathrm{T} 1$, whereas the ectopic expression of Antp resulted in $\mathrm{T} 1$ to $\mathrm{T} 2$ transformation. This may be attributed to a partial loss of functional specificity during evolution or, alternatively, to a convergent evolution of Antp and its vertebrate cognates. In this study we have shown that phenotypes induced by ectopic expression of Hox-1.3 are virtually identical to (if not stronger than) those of $h s-$ Scr. Thus, we suggest that an independent primordial gene for $S c r$ and Hox-1.3 existed in a primordial cluster of a common ancestor. Possibly, this gene was retained under more stringent selective pressure because it plays a more important role than an Antp-like gene for pattern formation in vertebrate development.

\section{How does a cognate maintain its regulatory specificity?}

The present study supports the previous finding that mammalian Hox genes can functionally substitute for cognate Drosophila homeotic selector genes in fruit flies (Malicki et al. 1990; McGinnis et al. 1990). For each one of the three examined cognate pairs [Antp/mouse Hox2.2 (Malicki et al. 1990), Dfd/human Hox-4.2 (McGinnis et al. 1990), and Scr/mouse Hox-1.3 (this paper)], comparison of primary amino acid sequence reveals only small regions of conservation, the strongest homology being in the homeo domain $157 / 61,54 / 60$, and 56/61, respectively). In addition, similarities in the octapeptide and pentapeptide regions between Scr and Hox-1.3 suggest that these regions may contribute to functional specificity as well. However, these regions of similarity are extremely short.

Thus, the remarkable specificities of these proteins seem to be based only on a few individual amino acids in conserved regions, relatively independent of the rest of the protein sequence. At the same time, however, functional specificity of different homeo box-containing genes is accomplished despite the striking similarities of their homeo domains (Antp vs. Scr, 56/61; Antp vs. Dfd, 49/60; and Scr vs. Dfd, 50/60). These analyses suggest that specificities of these proteins may be accomplished by secondary or tertiary protein structures whose exis- 
tence is not revealed by primary amino acid sequence analysis and whose function is to interact with auxiliary factors (Hayashi and Scott 1990). Furthermore, the combined results of the mouse/fly cognate experiments suggest that position within a Hox cluster may be more predictive of function than is analysis of primary amino acid sequence.

Although the different members of mouse Hox complexes are expressed in patterns having unique anterior boundaries, there are large regions of the body in which several members of each complex are expressed. For example, the expression domains of Hox-1.2, Hox-1.3, and Hox-1.4 partially overlap (Gaunt et al. 1988, 1989, 1990; Dressler and Gruss 1989). In flies, the $f k h$ gene is activated by ectopic expression of Scr but not Antp (Panzer et al. 1992). The observation that the $f k h$ gene is activated by Hox-1.3 in flies suggests that it might have the ability to regulate specific genes that are not regulated by other members of the Hox-1 cluster, for example, Hox1.2, the Antp cognate. A further speculation is that each Hox gene may thus regulate different sets of target genes. The overlapping expression of different combinations of Hox genes in the mouse embryo would thereby provide a combinatorial code that would give each cell in the developing embryo a unique identity.

\section{Hox-1.3 activates a downstream gene of Scr}

The ectopic activation of $f k h$ after the induction of mouse Hox-1.3 in fly embryos provides the first molecular evidence to support the notion that mammalian Hox gene products can activate a target gene of an insect homeotic selector gene and participate in the genetic circuitry of Drosophila. The transformation and the activation of the $f k h-l a c Z$ fusion gene observed in $h s-H o x-1.3-$ bearing animals do not appear to be attributable to the activation of the endogenous cognate $S c r$ gene, as ectopic expression of $\mathrm{Scr}$ is not observed after induction. Panzer et al. (1992) pointed out that the action of $S c r$ on $f k h$ expression is restricted to the early phase of embryogenesis (within $4 \mathrm{hr} \mathrm{AEL}$ ). After that, Scr is unable to induce $f k h$ ectopically. The response time phase of $f k h$ to $S c r /$ Hox-1.3 induction further supports the hypothesis that Hox -1.3 directly activates $f k h$ transcription. In $h s-H o x-$ 1.3/fkh-lacZ-bearing hybrid embryos, the ectopic presence of $\beta$-galactosidase is indistinguishable from that of $h s-S c r / f k h-l a c Z$ embryos (see Fig. 7). It is unlikely to be mediated by activation of the endogenous $S c r$ gene after heat-induced expression of Hox-1.3, because the Scr gene has an $\sim 25$-kb-long transcription unit (LeMotte et al. 1989). Thus, enough Scr protein products would only accumulate after the sensitive period for $f k h$ induction in hs-Hox-1.3 embryos.

It is possible that the extent of conservation in developmental programs between vertebrates and invertebrates is far more than expected. Sequence comparison reveals that the mammalian HNF-3 gene family, whose products were originally purified from rat liver nuclear extracts, is the counterpart to Drosophila $f k h$ (Lai et al. 1991). Similar to $f k h$, which is specifically expressed in gut and salivary gland tissues, the HNF-3 family is also expressed at different levels in the organs or tissues (such as liver, lung, and intestine etc.) derived from the embryonic gut tube. Lai et al. (1991) suggested that the HNF-3 family may maintain certain $f k h$ functions in forming gut-related terminal embryonic structures during evolution (Lai et al. 1991). Interestingly, Hox-1.3 transcripts also have been found in liver and lung (Odenwald et al. 1987; Garbern et al. 1989). The colocalization of Hox-1.3 and HNF-3 gene products in the same tissues may not be a coincidence. Rather, the mammalian Hox1.3 may participate in organogenesis by activating HNF-3 in a particular group of cells, as $S c r$ and $f k h$ dictate the ontogenesis of the Drosophila salivary gland. The HNF-3 products, a new class of transcription factors, may then act on downstream targets to direct the formation of terminal organ structures.

\section{Materials and methods}

\section{DNA construction}

The P-element vector CaSpeR-hs (Pirotta 1988) was cleaved within the polylinker sites with restriction enzymes $\mathrm{HpaI}$ and $\mathrm{XbaI}$. A full-length Hox-1.3-coding sequence from plasmid pCDM81.35 + lobtained from W. Odenwald, National Institutes of Health, Bethesda, MD/ was cleaved with Xhol. Protruding ends were filled in with Klenow enzyme, and the linerized DNA was digested with $\mathrm{XbaI}$. The fragment produced by this manipulation contains the Hox-1.3 ORF flanked by the $5^{\prime}$ end TCGAGCAACAAGGAA linker and the $3^{\prime}$ end GCATCTGAGCGGCCAAA GTACTGTCGACTCTAGA untranslated sequence. The fragment and the vector DNA were ligated together to generate $h s-H o x-1.3$. Standard methods were used for all procedures (Sambrook et al. 1989).

\section{Transgenic flies}

Flies were grown at $25^{\circ} \mathrm{C}$ on standard medium containing cornmeal, sugar, yeast, and agar. P-element transformation of $D f(1)$ w embryos was carried out using standard techniques with the helper plasmid p $\pi 25.1 \mathrm{wc}$ (Rubin and Spradling 1982; Karess and Rubin 1984). Stocks were maintained as homozygous or with the balancer chromosomes $y w / C y O$ or $y w / T M 6 b$. All experiments were repeated with three or more of the 10 independent transformant lines established to rule out positional effects of insertion.

Three independent $h s-S c r$ lines were kindly provided by $D$. Andrew, W-L. Zeng, and M. Scott (Stanford University, CA). $\mathrm{P}\left[\mathrm{ry}^{+}\right.$, HNK01] carrying a $f k h$ enhancer-lacZ fusion gene was a gift from B. Zhou and S. Beckendorf (University of California, Berkeley, CA).

\section{Heat treatment and phenotypic analysis}

Heat shock treatments were performed as described by Gibson and Gehring (1988; G. Gibson, pers. comm.) except for some modification. For examining the cuticular consequences of heat shock, embryos are precollected on yeasted apple juice plates for $1 \mathrm{hr}$ and collected on fresh yeasted apple juice plates for $30 \mathrm{~min}$. They are allowed to mature at $25^{\circ} \mathrm{C}$ for $\sim 5.5-6 \mathrm{hr}$ until heat shock treatment. Embryos are immersed in still water of a $37^{\circ} \mathrm{C}$ water bath for $60 \mathrm{~min}$. After heat shock treatment, the embryos are allowed to mature further for another $20 \mathrm{hr}$ on plain apple juice plates. They are dechorionated in $3 \%$ sodium hypochlorite 
(supplied by VWR Scientific) for $2 \mathrm{~min}$, and vitelline membranes are removed by shaking vigorously in heptane/methanol (1:1) solution. After washing twice with methanol, embryos are incubated in acetic acid/glycerol $(4: 1)$ at $45^{\circ} \mathrm{C}$ for 2 days and mounted in Hoyer's medium/lactic acid $(1: 1)$ on a glass slide (Van der Meer 1977). They are placed at $45^{\circ} \mathrm{C}$ for 1 week. The cuticular structures are analyzed and photographed using dark-field and phase-contrast microscopy. By delivering a 20min heat shock at different times to hs-Hox-1.3 embryos, we found that the most sensitive stage to ubiquitous Hox-1.3 expression was at $5-6 \mathrm{hr}$ AEL; $70 \%$ of the treated embryos were not able to hatch to first-instar larvae.

For larval heat shock, embryos are collected for $1 \mathrm{hr}$, washed, and allowed to age on plain apple juice plates at $25^{\circ} \mathrm{C}$ for $24 \mathrm{hr}$. To test in which period hs-Hox-1.3 larvae would be affected most severely by heat shock, hatched larvae were picked and inoculated into several yeasted cornmeal vials, in batches of 20 . Animals in each vial grew at $25^{\circ} \mathrm{C}$ to a predetermined stage and were heat-shocked at $36.8^{\circ} \mathrm{C}$ for $45 \mathrm{~min}$ (heat shock is given to individual vials at 3 -hr intervals starting at $48 \mathrm{hr}$ and ending at $120 \mathrm{hr}$ AEL). To obtain stronger transformations, heat shock is given multiple times, usually from 68 to $92 \mathrm{hr}$ AEL at $36.8^{\circ} \mathrm{C}$ for $45 \mathrm{~min}$ with minimal 4 -hr intervals. Heat is delivered to animals by simply placing the vials in a $36.8^{\circ} \mathrm{C}$ water bath. It was found that the temperature of the water bath is crucial, and a $0.3^{\circ} \mathrm{C}$ higher temperature could kill all larvae before they reach the pupal stage. After heat shock, usually, $70-80 \%$ of the larvae die before eclosion (for $h s-S c r$ flies, $>90 \%$ die). Adult flies and unhatched pupae (that were first dissected out of sacs) are treated as described by McGinnis et al. (1990).

\section{Immunohistochemical staining}

Embryos are allowed to age $6 \mathrm{hr}$ and are heat-shocked for the indicated time. For Hox-1.3 antibody staining, the heat treatment is for $1 \mathrm{hr}$ and embryos are recovered at $25^{\circ} \mathrm{C}$ for $1 \mathrm{hr}$. For Scr and Dfd antibody staining, embryos are heat-shocked for 1 $\mathrm{hr}$ and allowed to recover at $25^{\circ} \mathrm{C}$ for $3 \mathrm{hr}$ and $2 \mathrm{hr}$, respectively. Embryo collection and heat treatment for the $f \mathrm{kh}$ enhancerlacZ construct is according to the previous description (Panzer et al. 1992). Immunostaining is carried out by modifications of standard methods (T. Gutjahr and M. Noll, pers. comm.) using a preformed $\mathrm{ABC}$ (avidin and biotinylated horseradish peroxidase macromolecular complex) reagent (Vectastain Elite ABC $\mathrm{Kit}$. The Hox-1.3 epitope is located in a nonconserved region from amino acid residue 53 to 72 , and the preparation of Hox-1.3 antiserum was described previously (Odenwald et al. 1987). The Scr and Dfd monoclonal antisera are gifts from D. Brower and W. McGinnis. The anti- $\beta$-galactosidase antibody is from Cappell. Imaginal disc staining was carried out as described by Pattatucci and Kaufman (1991).

\section{Photography}

The immunostaining embryos were photographed with Nomarski optics, and the larval cuticles were photographed in dark field on a Zeiss Axiophot microscope. The adults were photographed on an Olympus BH-2 microscope. We used Kodak TMAX100 film for black and white photography and Ektachrome ET160 film for color photography. Films were processed with Adobe Photoshop Macintosh Version 2 (Adobe Systems Inc.) and printed on a Kodak XL7700 printer.

\section{Acknowledgments}

We are grateful to the members of Matthew Scott's laboratory, particularly D. Andrew and W.-L. Zeng for providing us with hs-Scr-bearing flies and information before publication. We wish to thank W. McGinnis for the anti-Dfd monoclonal antibody, D. Brower for the anti-Scr and anti-Antp sera; W. Odenwald for the Hox-1.3 cDNA construct (pCDM81.35+) and antiserum, C. Rushlow for the heat shock vector, B. Zhou and S. Beckendorf for providing the $\mathrm{P}\left[\mathrm{ry}^{+}, \mathrm{HNK01}\right]$ strain, and $\mathrm{H}$. Stuhlmann for critical comments on the manuscript. We are grateful to Greg Gibson for encouragement and advice during the course of the project and for helpful comments on the manuscript. This work was supported by a grant to L.P. from the National Institutes of Health (HD 27937-O1A1). L.P. was a recipient of an Alexandrine and Alexander Sincheimer Award and an Irma T. Hirchl Career Scientist Award. This is publication 121 from the Brookdale Center for Molecular Biology.

The publication costs of this article were defrayed in part by payment of page charges. This article must therefore be hereby marked "advertisement" in accordance with 18 USC section 1734 solely to indicate this fact.

\section{Note}

The new nomenclature for Hox-1.3 is HoxA5 (Scott 1992).

\section{References}

Akam, M.E. 1987. The molecular basis for metameric pattern in the Drosophila embryo. Development 101: 1-22.

Akam, M., I. Dawson, and G. Tear. 1988. Homeotic genes and the control of segment diversity. Development 104: 123133.

Chisaka, O. and M.R. Capecchi. 1991. Regionally restricted developmental defects resulting from targeted disruption of the mouse homeo box gene Hox-1.5. Nature 350: 473-479.

Colberg-Poley, A.M., S.D. Voss, K. Chowdhury, and P. Gruss. 1985. Structural analysis of murine genes containing homeo box sequences and their expression in embryonal carcinoma cells. Nature 314: 713-718.

Desplan, C., J. Theis, and P.H. O'Farrell. 1985. The Drosophila developmental gene, engrailed, encodes a sequence-specific DNA binding activity. Nature 318: 630-635.

- 1988. The sequence specificity of homeo domain-DNA interaction. Cell 54: 1081-1090.

Dony, C. and P. Gruss. 1987. Specific expression of the Hox-1.3 homeo box gene in murine embryonic structures originating from or induced by the mesoderm. EMBO I. 6: 2965-2975.

Dressler, G.R. and P. Gruss. 1989. Anterior boundaries of Hox gene expression in mesoderm-derived structures correlate with the linear gene order along the chromosome. Differentiation 41: 193-201.

Duboule, D. and P. Dolle. 1989. The structural and functional organization of the murine HOX gene family resembles that of Drosophila homeotic genes. EMBO I. 8: 1497-1505.

Duncan, I. and E.B. Lewis. 1982. Genetic control of body segment differentiation in Drosophila. In Developmental order: Its origin and regulation (ed. S. Subtelny and P.B. Green), pp. 533-554. Alan R. Liss, New York

Fainsod, A., L.D. Bogarad, T. Ruusala, M. Lubin, D.M. Crothers, and F.H. Ruddle. 1987. The homeo domain of a murine protein binds $5^{\prime}$ to its own homeo box. Proc. Natl. Acad. Sci. 83: 9532-9536.

Fibi, M., B. Zink, M. Kessel, A.M. Colberg-Poley, S. Labeit, H. Lehrach, and P. Gruss. 1988. Coding sequence and expression of the homeo box gene Hox 1.3. Development 102: 349359.

Garbern, J., W. Odenwald, E. Tournier-Lasserve, and R. Lazzarini. 1989. Analysis of transcription of the murine homeo 
box gene Hox-1.3. NATO ASI Series H26 (ed. S. deLaat, J.G. Bluemink, and C.L. Mummeryl, pp. 63-73. Springer-Verlag, Berlin, Germany.

Gaunt, S.J., P.T. Sharpe, and D. Duboule. 1988. Spatially restricted domains of homeo-gene transcripts in mouse embryos: Relation to a segmented body plan. Development 104: 169-179.

Gaunt, S.J., R. Krumlauf, and D. Duboule. 1989. Mouse homeogenes within a subfamily, Hox-1.4, -2.6 and -5.1, display similar anteroposterior domains of expression in the embryo, but show stage- and tissue-dependent differences in their regulation. Development 107: 131-141.

Gaunt, S.J., P.L. Coletta, D. Pravtcheva, and P.T. Sharpe. 1990. Mouse Hox-3.4: Homeo box sequence and embryonic expression patterns compared with other members of the Hox gene network. Development 109: 329-339.

Gibson, G. and W.J. Gehring. 1988. Head and thoracic transformations caused by ectopic expression of Antennapedia during Drosophila development. Development 102: 657-675.

Gibson, G., A. Schier, P. LeMotte, and W.J. Gehring. 1990. The specificities of Sex Combs Reduced and Antennapedia are defined by a distinct portion of each protein that includes the homeo domain. Cell 62: 1087-1103.

González-Reyes, A. and G. Morata. 1990. The developmental effect of overexpressing a Ubx product in Drosophila embryos is dependent on its interactions with other homeotic products. Cell 61: 515-522.

González-Reyes, A., N. Urquia, W.J. Gehring, G. Struhl, and G. Morata. 1990. Are cross-regulatory interactions between homoeotic genes functionally significant? Nature 344: 78-80.

Graham, A., N. Papalopulu, and R. Krumlauf. 1989. The murine and Drosophila homeo box gene complexes have common features of organization and expression. Cell 57: 367-378

Hafen, E., M. Levine, and W.J. Gehring. 1984. Regulation of Antennapedia transcript distribution by the bithorax complex in Drosophila. Nature 307: 287-289.

Hall, M.N. and A.D. Johnson. 1987. Homeo domain of the yeast repressor alpha 2 is a sequence specific DNA-binding domain but is not sufficient for repression. Science 237: 10071012.

Harding, K., C. Wedeen, W. McGinnis, and M. Levine. 1985. Spatially regulated expression of homeotic genes in Drosophila. Science 229: 1236-1242.

Hayashi, S. and M.P. Scott. 1990. What determines the specificity of action of Drosophila homeo domain proteins? Cell 63: 883-894.

Heuer, J.G. and T.C. Kaufman. 1992. Homeotic genes have specific functional roles in the establishment of the Drosophila embryonic peripheral nervous system. Development 115: 35-47.

Hoey, T., R. Warrior, J. Manak, and M. Levine. 1988. DNAbinding activities of the Drosophila melanogaster evenskipped protein are mediated by its homeo domain and influenced by protein context. Mol. Cell. Biol. 8: 4598-4607.

Jack, T., M. Regulski, and W. McGinnis. 1988. Pair-rule segmentation genes regulate the expression of the homeotic selector gene, Deformed. Genes \& Dev. 2: 635-651.

Karess, R.E. and G.M. Rubin. 1984. Analysis of P transposable element functions in Drosophila. Cell 38: 135-146.

Kissinger, C.R., B. Liu, E. Martin-Blanco, T. Kornberg, and C.O. Pabo. 1990. Crystal structure of an engrailed homeo domainDNA complex at 2.8 A resolution: A framework for understanding homeo domain-DNA interactions. Cell 63: 579590.

Kuziora, M.A. and W. McGinnis. 1988. Autoregulation of a Drosophila homeotic selector gene. Cell 55: 477-485.
1989. A homeo domain substitution changes the regulatory specificity of the Deformed protein in Drosophila embryos. Cell 59: 563-571.

Lai, E., V.R. Prezioso, W. Tao, W.S. Chen, and J.E. Darnell. 1991. Hepatocyte nuclear factor $3 \alpha$ belongs to a gene family in mammals that is homologous to the Drosophila homeotic gene fork head. Genes \& Dev. 5: 416-427.

LeMotte, P.K., A. Kuroiwa, L.I. Fessier, and W.J. Gehring. 1989. The homeotic gene Sex Combs Reduced of Drosophila: Gene structure and embryonic expression. EMBO J. 8: 219227.

Le Mouellic, H., Y. Lallemand, and P. Brûlet. 1992. Homeosis in the mouse induced by a null mutation in the Hox-3.1 gene. Cell 69: 251-264.

Lufkin, T., A. Dierich, M. LeMeur, M. Mark, and P. Chambon. 1991. Disruption of the Hox-1.6 homeo box gene results in defects in a region corresponding to its rostral domain of expression. Cell 66: 1105-1119.

Malicki, J., K. Schughart, and W. McGinnis. 1990. Mouse Hox2.2 specifies thoracic segmental identity in Drosophila embryos and larvae. Cell 63: 961-967.

Mann, R.S. and D.S. Hogness. 1990. Functional dissection of Ultrabithorax proteins in D. melanogaster. Cell 60: 597610.

McGinnis, W. and R. Krumlauf. 1992. Homeo box genes and axial patterning. Cell 68: 283-302.

McGinnis, W., M.S. Levine, E. Hafen, A. Kuroiwa, and W.J. Gehring. 1984a. A conserved DNA sequence in homeotic genes of the Drosophila Antennapedia and bithorax complexes. Nature 308: 428-433.

McGinnis, W., R.L. Garber, J. Wirz, A. Kuroiwa, and W.J. Gehring. 1984b. A homologous protein-coding sequence in Drosophila homeotic genes and its conservation in other metazoans. Cell 37: 403-408.

McGinnis, N., M.A. Kuziora, and W. McGinnis. 1990. Human Hox-4.2 and Drosophila Deformed encode similar regulatory specificities in Drosophila embryos and larvae. Cell 63: 969976.

Müller, M., M. Affolter, W. Leupin, G. Otting, K. Wuthrich, and W.J. Gehring. 1988. Isolation and sequence-specific DNAbinding of the Antennapedia homeo domain. EMBO I. 7: 4299-4304.

Odenwald, W.F., C.F. Taylor, F.J. Palmer-Hill, J.V. Friedrich, M. Tani, and R.A. Lazzarini. 1987. Expression of a homeo domain protein in noncontact-inhibited cultured cells and postmitotic neurons. Genes \& Dev. 1: 482-496.

Odenwald, W.F., J. Garbern, H. Arnheiter, E. Tournier-Lasserve, and R.A. Lazzarini. 1989. The Hox-1.3 homeo box protein is a sequence-specific DNA-binding phosphoprotein. Genes \& Dev. 3: 158-172.

Panzer, S., D. Weigel, and S.K. Beckendorf. 1992. Organogenesis in Drosophila melanogaster: Embryonic salivary gland determination is controlled by homeotic and dorsoventral patterning genes. Development 114: 49-57.

Pattatucci, A.M. and T.C. Kaufman. 1991. The homeotic gene Sex combs reduced of Drosophila melanogaster is differentially regulated in the embryonic and imaginal stages of development. Genetics 129: 443-461.

Pattatucci, A.M., D.C. Otteson, and T.C. Kaufman. 1991. A functional and structural analysis of the Sex combs reduced locus of Drosophila melanogaster. Genetics 129: 423-441.

Pirotta, V. 1988. Vectors for P-mediated transformations in Drosophila. In Vectors: A survey of molecular cloning vectors and their uses (ed. R.L. Rodriguez and D.T. Reinhardt), pp. 437-456. Butterworths, Boston, MA.

Regulski, M., N. McGinnis, R. Chadwick, and W. McGinnis. 
1987. Developmental and molecular analysis of Deformed: A homeotic gene controlling Drosophila head development. EMBO I. 6: 767-777.

Riley, P.D., S.B. Carroll, and M.P. Scott. 1987. The expression and regulation of Sex combs reduced protein in Drosophila embryos. Genes \& Dev. 1: 716-730.

Rubin, G.M. and A.C. Spradling. 1982. Genetic transformation of Drosophila with transposable element vectors. Science 218: 348-353.

Sambrook, J., E.F. Fritsch, and T. Maniatis. 1989. Molecular cloning: A laboratory manual, 2nd ed. Cold Spring Harbor Laboratory Press, Cold Spring Harbor, New York.

Schneuwly, S., A. Kuroiwa, P. Baumgartner, and W. Gehring. 1986. Structure organization and sequence of the homeotic gene Antennapedia of Drosophila melanogaster. EMBO $\mathrm{I}$. 5: 733-739.

Schneuwly, S., R. Klemenz, and W.J. Gehring. 1987. Redesigning the body plan of Drosophila by ectopic expression of the homoeotic gene Antennapedia. Nature 325: 816-818.

Scott, M.P. 1992. Vertebrate homeo box gene nomenclature. Cell 71: 551-553.

Scott, M.P. and A.J. Weiner. 1984. Structural relationships among genes that control development: Sequence homology between the Antennapedia, Ultrabithorax and fushi tarazu. Proc. Natl. Acad. Sci. 81: 4115-4119.

Scott, M.P., J.W. Tamkun, and I.G.W. Hartzell. 1989. The structure and function of the homeo domain. Biochim. Biophys. Acta 989: 25-48.

Spradling, A.C. and G.M. Rubin. 1982. Transposition of cloned P-elements into Drosophila germ line chromosomes. Science 218: 341-347.

Tani, M., W.F. Odenwald, R.A. Lazzarini, and J.V.L. Friedrich. 1989. Progressive restriction in the distribution of the Hox1.3 homeo domain protein during embryogenesis. I. Neurosci. Res. 24: 457-469.

Treisman, J., P. Gonczy, M. Vashishtha, E. Harris, and C. Desplan. 1989. A single amino acid can determine the DNA binding specificity of homeo domain proteins. Cell 59: 553562.

Van der Meer, J.M. 1977. Optical clean and permanent whole mount preparation for phase contrast microscopy of cuticular structures of insect larvae. Dros. Inf. Serv. 52: 160.

Weigel, D., E. Seifert, D. Reuter, and H. Jäckle. 1990. Regulatory elements controlling expression of the Drosophila homeotic gene fork head. EMBO I. 9: 1199-1207. 


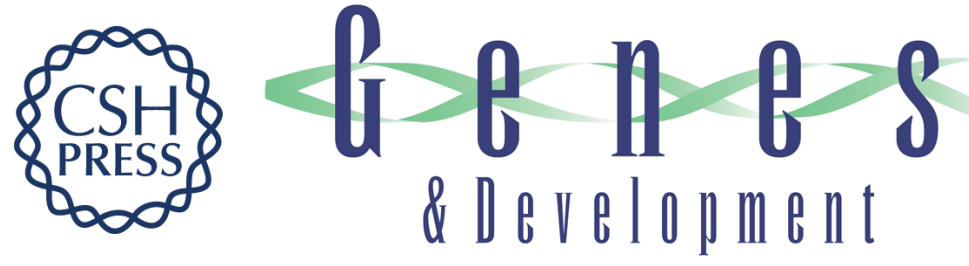

\title{
The mouse Hox-1.3 gene is functionally equivalent to the Drosophila Sex combs reduced gene.
}

\author{
J J Zhao, R A Lazzarini and L Pick
}

Genes Dev. 1993, 7:

Access the most recent version at doi:10.1101/gad.7.3.343

References This article cites 59 articles, 22 of which can be accessed free at:

http://genesdev.cshlp.org/content/7/3/343.full.html\#ref-list-1

\section{License}

Email Alerting

Service

Receive free email alerts when new articles cite this article - sign up in the box at the top right corner of the article or click here.

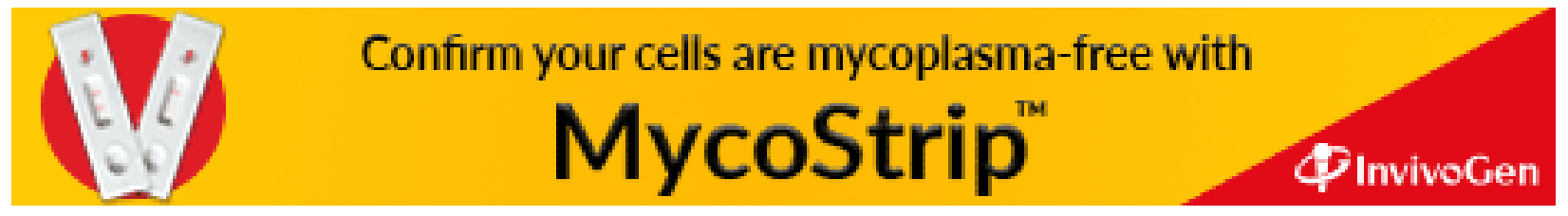

